\title{
Women's Language Used in the Video of Counter Strike: Global Offensive Female Player
}

\author{
Komang Satria Wirasa ${ }^{1 *}$, I Made Winaya ${ }^{2}$ \\ ${ }^{[12]}$ English Department - Faculty of Arts - Udayana University \\ 1[satria.wirasa@gmail.com] 2[made_winaya@unud.ac.id] \\ *Corresponding Author
}

\begin{abstract}
This paper entitled Women Language Used in Video of Counter strike: Global Offensive Female Player. This study aimed at identifying the language features applied by a woman when she played a game entitled Counter Strike: Global Offensive and find out the language style of the utterances in her conversation. The data source of this study was taken from the conversation used by Counter Strike: Global Offensive female players in the video. The collecting data used documenting method and it begins with listen to the conversation in the video and then made a transcript, afterwards, sorted out and categorized the data into women's linguistic feature and language style. Thereafter, the data analyzed by using quantitative method The findings of this study showed the utterance produced by the female player include sixteen data of women language features and three out of six styles of women language in this video.
\end{abstract}

Key words: women language, linguistic feature, language style

Abstrak

Penelitian ini berjudul bahasa wanita yang digunakan di vidio Counter Strike: Global Offensive pemain perempuan. Penelitian ini bertujuan unutk mengidentifikasi fitur dari bahasa perempuan dan mengetahui gaya bahasa yang digunakan oleh perempuan yang sedang bermain Counter Strike: Global Offensive. Sumber data yang digunakan pada penelitian ini didapatkan dari sebuah vidio yang diupload di internet. Penelitian ini menggunakan metode dokumentasi meliputi pengamatan vidio kemudian membuat salinan percakapan yang di ucapkan oleh para pemain, dan mengelompokan data yang didapat berdasarkan fitur dan gaya bahasa wanita. Setelah itu, data yang sudah didapatkan dianalisis menggunakan metode kuantitatif. Hasil dari penelitian ini menunjukan bahwa ucapan yang diungkapkan oleh wanita di vidio ini ditemukan.

Kata kunci: Bahasa Wanita, Fitur Bahasa Wanita, Gaya Bahasa Wanita

\section{Background}

A powerful commonsense about men and women language circulates widely in our society and culture. Thereafter, many linguists analyzed and characterized this topic as language and gender. Coates (2013: 4) defines the different of styles when using a language depends on several things; those are educational background, social status, age, and gender.

At this time multiplayer online game played by many people, not least by women. One of the games that women are interested in is CS: GO. When CS:GO plays more than 300,000 peoples (based on steam on 2017), women have their own way to participate in this game, it shows when women make their 
channel in some website or join some international tournaments. As one of parts in the game, women should interact with the other player to complete some purposes such as, win or complete some missions in the game.

In relation to this study, this game selected as the object of the study since this game could show the features of women language an also the CS: GO is one of favorite game. Based on Steam as digital distribution for many games, it predicate in second position on top games by current player count at 2017 . Hereafter, many study have been described the analysis of women language, however, there were still lots pros and contras that can be describe on this topic. Therefore, women's language becomes very interesting topic to be studied.

\section{Problem of the Study}

In accordance with the background above, there are two problems that can be

formulated related to this topic, those are:

a. What types of women's linguistic features are used by the CS:GO female players?

b. What kind of women's language styles are found in the video of CS:GO female players?

\section{Aims of the Study}

Based on problems of this study, there are two aims related to the problem proposed above, as follows.

a. To find out the types of women's linguistic features used in the video of Counter Strike: Global Offensive female player.

b. To identify the kind of women's language styles used in the video of Counter Strike: Global Offensive female player.

\section{Research method}

The data of this study took from a video which uploaded in video-sharing website. It is taken the conversation used by CS: GO female players in the video entitled GOVER GOES TO PROM $(C S: G O)$, which uploaded in January $6^{\text {th }}$, 2016 on channel 2MGLasoo at Youtue.com. The data collected used documentation method

To collect the data this study used documentation method. And the technique of collecting data started by watched the video. After that, made a transcript of the video based on the conversation uttered by all players. And then, listening to the conversation produced by the female player in the video as well as read the transcript to get the data. And the last one the data then sorted out based on the theory applied.

This study used quantitative method to analyze the data. Firstly, read the data from the note which got in collecting data. Secondly, classified the data into two parts; first one was women's linguistic features, and the second one was women's language styles. And finally, the data is analyzed base on theory applied.

The results of analyzing data were presented descriptively and used informal methods, the steps begin with the data grouped based on their types. After that, the theory applied to analyze the data in this study. Then, the data categorized based on types of women's linguistic features and language styles. Finally, the data explained descriptively.

\section{Findings and Discussion}

\subsection{The Analysis of Women's Linguistic Features 5.1.1 Lexical Hedges or Fillers} The female player 'blue' : should I sing a song that help you clutch?

Her teammate 'yellow' : I do like to request hello 
The female player 'blue' : alright, next time you need in a clutch, I will sing hello

Her teammate 'yellow' : I don't like that song so much

The female player 'blue' : well, what songs do you like Justin!?

*but her teammates ignore her question and questioning about the name "Justin"

The female player used hedges well since she was not sure exactly what songs of her teammates want in his clutch. As we can see, the world well in this case expressed that she used it to make a question intonation to give the impression because she was lack of authority.

\subsubsection{Rising or Question Intonation on Declaratives}

The female player 'blue' : should I sing a song that help you clutch?

Her teammate 'yellow' : I do like to request hello

The female player 'blue' : alright, next

time you need in a clutch, I will sing

hello

Her teammate 'yellow' : I don't like

that song so much

The female player 'blue' : well, what

songs do you like Justin? $\nearrow$

In the female player's utterance, she used rising notation in his declarative to get the confirmation from her teammates. In this outrace, the function of this rising intonation or question on declarative is used when the speaker (female player) is dig up for a confirmation to someone in a unsure speech as though as the same time the speaker may be the only one who has the requisite information.

\subsubsection{Use of Empty Adjective}

The female player 'blue' : (excited) like Kryoz scheming on youtube?!

Her teammate 'yellow' : yeah
The female player 'blue' : oh my Gosh, I'm a huge fans

In this case, that utterance contains word huge which tends to empty adjective. The function of empty adjective to women is to show the speaker's approbation or admiration for something. The female player in this video used empty adjective huge in her statement since she also excited with her teammate's statement about he is Kyroz. In this context, she tends to use adjective huge for representing herself as the Kryoz's number one fans.

\subsubsection{Use of Intensifiers}

The female player 'blue' : you're so good in this game Jamie

In the female player's conversation (1) above addressed to her teammate after he finished the rounds. In this statement she shows to her teammate who can be better than her in the game. When she died because she got shot by her opponent, her teammate could finish the rounds well. She uttered this intensive adverb so in her statement "you're so good in this game Jamie" to strengthen her feeling in this utterance which her teammate played well since the match started.

\subsubsection{Hypercorrect Grammar}

The female player 'blue' : yellow, would you go to prom with me?

Her teammates 'yellow' : um, I think I have a date, but if it only half, sure

In this utterance, the female player uttered yellow, would you go to prom with me? In her utterance it purposes to represent the politeness between the speaker (the female player) and listener (female player's teammate) in her statement. Furthermore, the conversation above indicates the hypercorrect grammar when she used future tense in interrogative form in this invitation. "would you go to prom with 
me?". This was considered she used the Standard English as the female player wanted to make a polite form in her invitation.

\subsubsection{Avoidance of Strong Swear Words}

The female player 'blue' :(her teammate surrounded with their opponent (terrorists)) oh my Gosh,, oh my Gosh, Jobba,, oh,,(her teammate died), ah..... Her teammates 'yellow' : I'm so sorry The female player 'blue' : that was beautiful though

The word 'Gosh' used as an euphemism or has a sameness as word God. In this condition, the word my Gosh expresses her emotion at that situation where she watches her teammate faces up their opponent and got shot by them. In her statement, the female player prefers to use utterance oh my Gosh in purpose to weaken her strong swear.

\subsection{The Analysis of Women's language styles}

\subsubsection{Question}

The female player 'blue' : yellow, would you go to prom with me?

Her teammate 'yellow' : um, I think I have a date, but if it only half, sure

The female player 'blue' : (laughing)

What's your day?, who's your date?

The female player 'blue' : in the middle of her match, she met with her opponent and reflexively shot each other) oh my God, I got it right!?

The female player 'blue' : Do you love your date? Is she your girlfriend? How long you two been dating?

Her teammate 'yellow' : I guess a little over year

In his utterances reflect women's relative weakness in interactive conversation, women use tag question and more question in their speech to hold the conversation going. In the utterances above was seen the questions addressed to female player's teammate to keep the conversation still continue and also to discuss her curious and stated lots of question about the teammate's statement who rejected her invitation because he already has a date.

\subsubsection{Commands and Directives}

Her teammates 'yellow' : so, they are plant bomb on site B?

The female player 'blue' : they are on $B$, (the bomb planted by terrorist) they planted. They are all alive

Her teammates 'orange' : one B

The female player 'blue' :( she kill a terrorist) we gonna make moves. (Focus shoots a terrorist but she killed) whoa, watch yourself back

The form gonna explicitly includes the speaker related with the addressee(s) in the proposed action; the mitigated' directives is hardly used by boys. She used this utterance to try directing and inviting her teammates went to the $\mathrm{B}$ point or where the bomb planted because they did not have time left since they were late to realize where the bomb planted.

\subsubsection{Swearing and Taboo language}

In this style analyzed the nine particles of swear and taboo languages which uttered by the female player. In this analysis the female player uttered six utterances reflected the female player tried to avoid the strong swear word and show how she uttered the weaker particles when swearing. Therefore, the female player used the three strong particle which indicate the vulgar language. Coates stated taboo words are utterances which could come under the general heading of vulgar language. In addition, the female player uttered both strong and weak particles with different intensity of usage. Moreover the most of her swear and taboo languages were weak particles. According to Coates, 
women tend to use weak swear word such as, dear God and my Goodness.

\section{Conclusions}

Based on the discussion, there are some points that could be presented as a conclusion of this research as follows:

First, there are six features of women's language found in this study, there are: two data of lexical hedger or fillers. Three data of rising or question intonation on declaratives. Three data using empty adjective. One data when the female player uses intensifiers. One data shows hypercorrect grammar. Six data of avoidance of strong swear words. Second, there are three out of five women language's styles as it had been proved in previous chapter such as: question, commands and directives and swearing and taboo language.

\section{References}

Coates, J. (1986). Women, Men, Language. New York: Longman.

Coates, J. (2013).Women, Men and Language: A Sociolinguistic Account of Gender. Differences in Language. New York: Routledge.

Lakoff, R. (1973). Language and Women's Place. Language in society. Vol 2, no.1, pp45-80

Lakoff, R. (1975). Language and women's place. New York: harper \& row.

Tannen, D.1992. You Just Don't Understand: women and Men in conversation. London: virago press. 